\title{
Heterotrophic nutrition and control of bacterial density in the coelenteron of the giant sea anemone Stoichactis giganteum
}

\author{
G. J. Herndl, B. Velimirov \& R. E. Krauss \\ Institut für Zoologie der Universität Wien, Althanstraße 14, Wien, Austria
}

\begin{abstract}
Contents of gastral cavities of giant sea anemones Stoichactis giganteum Forskal, sucked out in situ by means of a syringe, revealed that echinoids (Tripneustes sp.), brittle stars (Ophiothrix sp.) and large benthic decapods constitute the most important heterotrophic food source of $S$. giganteum. Additionally, a bacterial population within the gastral cavity was observed. Mean bacterial density was $2.49 \times 10^{6}$ cells ml-1. Rod-shaped bacteria contributed about $90 \%$ to the number of bacteria in the gastral cavity; their density was 14 times higher than that of rods in ambient waters. Laboratory experiments with starved and fed anemones revealed a rhythmic variation pattern in the bacterial density. During starvation bacterial density dropped to $0.98 \times 10^{5}$ cells $\mathrm{ml}^{-1}$. A net increase in density was observed after feeding within 4 to $5 \mathrm{~h}$, followed by a decrease in the next 2 to $3 \mathrm{~h}$ for both rods and cocci. Incubation experiments with coelenteric fluid revealed its regulative function in controlling bacterial density in the coelenteron. During incubation of the coelenteric fluid of starved anemones, a build up of bacterial density was observed to $35.3 \times 10^{5}$ cells ml-1 within $4 \mathrm{~h}$, while the coelenteric fluid of fed anemones demonstrated a bacterial digestion ability which increased with increasing bacterial density of the coelenteron. Evidence is provided for the fact that these bacteria contribute only a minor portion of the total energy requirements of the anemone.
\end{abstract}

Symbiotic anthozoans are considered to be multitrophic systems, receiving energy from primary production of zooxanthellae (Muscatine 1980), zooplankton feeding (Porter 1974, Lasker 1976, Sebens 1977). detritus (Lewis \& Price 1975, Lewis 1977), and from dissolved organic matter (Stephens 1962), Schlichter 1978). DiSalvo (1971) and Sorokin (1973) fed labeled bacteria to corals and established that corals may be able to digest bacteria. Reimer (1971) tested the uptake of ${ }^{14} \mathrm{C}$-glycine by Zoanthus sandwichensis and concluded that uptake rates are insufficient to cover energy requirements. Because of the lack of any feeding response of $Z$. sandwichensis to zooplankton, Reimer (1971) discussed the possibility that zoanthids may feed on bacteria

Information on prey composition is generally scarce among anthozoans and substantially restricted to the more conspicuous group of corals (Muscatine 1973, Porter 1974), although larger anthozoan species seem to be more adequate for the use of the syringe method described by Porter (1978).

The present investigation was designed to analyze the composition of prey of the giant sea anemone Stoichactis giganteum, one of the largest-sized anthozoan species, and to evaluate the role of bacterial density in the coelenteron. The field study was carried out during summer 1983 off Ras Iwatine, North Coast of Kenya. Gut samples of $S$. giganteum were sucked out of the gastral cavity by means of a syringe, following the method described by Porter (1978). A PVC-tube with an inner diameter of $1.6 \mathrm{~cm}$ was mounted on a syringe with a capacity of $60 \mathrm{~cm}^{3}$. Gut samples with a volume of 200 to $250 \mathrm{ml}$ per anemone and one $50 \mathrm{ml}$ sample of ambient water were sucked using SCUBA equipment. The samples were fixed immediately with formalin to a final concentration of 5 to $10 \%$, and kept at $4{ }^{\circ} \mathrm{C}$ in darkness until analysis. Five $\mathrm{ml}$ of the preserved gut samples were used for determining bacterial density in the coelenteric fluid, employing the acridine orange direct counting (AODC) technique (Hobbie et al. 1977).

For each sample 2 replicate estimates were made. In each case, 30 randomly chosen fields with 10 to 30 bacteria cells were counted. Dimensions of rods $(n=100)$ and cocci $(n=60)$ were measured to obtain mean cell volumes. Attached bacteria were enumerated separately assuming that the number of bacteria settling on the upper side of the particle is the same as on the non-visible underside. Therefore the total number of attached bacteria was obtained using the coefficient 2 . Laboratory experiments were carried out to evaluate the role of bacteria in the gastral cavity and the possible interdependence between bacteria and coelenteric fluid. Two specimens of Stoichactis gigan- 
teum were placed in an aquarium and held 5 mo before experimentation under a 14:10 h light - dark photoperiod. Lighting was provided by cool white fluorescent lamps kept at about $16 \mu \mathrm{E} \mathrm{m}^{-2} \mathrm{~s}^{-1}$. Mytilus edulis meat was offered as food twice a week.

Coelenteric fluid was sucked from the center of the gastral cavity in order to avoid damage of mesenterial filaments using a blunted needle $(2 \mathrm{~mm}$ inner diameter), mounted on a $10 \mathrm{ml}$ syringe. Four $\mathrm{ml}$ of coelenteric fluid were sucked from an estimated total fluid volume of 200 to $300 \mathrm{ml}$ (Herndl unpubl.). Two $\mathrm{ml}$ of this coelenteric fluid were fixed immediately, and the remaining $2 \mathrm{ml}$ were incubated in scintillation vials for $4 \mathrm{~h}$ (Rodina 1972 ) at $23^{\circ} \mathrm{C}$, the water temperature, both of the aquarium and the in situ study site.

The number of free-living bacteria in the ambient water varied between $5.85 \times 10^{5}$ and $12.52 \times 10^{5}$ cells $\mathrm{ml}^{-1}$ with a mean of $9.51 \times 10^{5}$ cells $\mathrm{ml}^{-1}$ $\left(\mathrm{SD}=2.5 \times 10^{5}\right)$ during the $3 \mathrm{wk}$ investigation period. Mean cell volume was $0.61 \mu^{3}$ for rod-shaped bacteria, and $0.13 \mu \mathrm{m}^{3}$ for cocci. The number of bacteria attached to particles was 1 order of magnitude lower than that of free-living bacteria. A mean value of $2.1 \times 10^{4}$ cells $\mathrm{ml}^{-1}\left(\mathrm{SD}=0.66 \times 10^{4}\right)$ was obtained for attached bacteria. The highest portion of particulate matter in ambient water, other than bacteria, consisted of spicules which were rarely colonized by bacteria. Aggregations of particulate matter with a diameter of 0.05 to $0.5 \mathrm{~mm}$ were also abundant in all samples examined. They consisted of plant and animal remains (e.g. spicules, crustacean exuvia, diatom frustules) with inclusions of sediment grains. These aggregations provided micro-environments for bacteria. Most of the attached bacteria examined in this study settled onto such complex masses. Furthermore, diatom fragments,

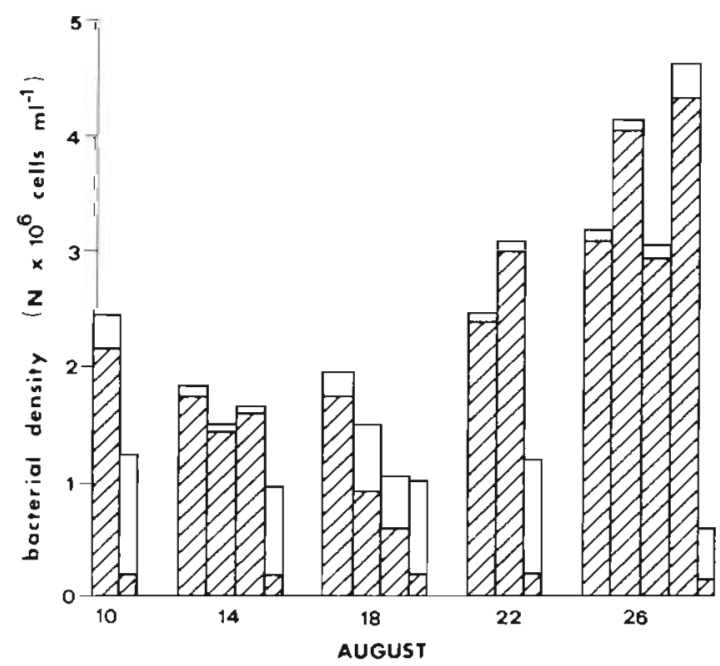

Fig. 1 Stoichactis giganteum. Bacterial densities in gastral cavities; small blocks: bacterial densities in ambient waters; shaded areas: rods; unshaded areas: cocci algal debris, flagellates, foraminiferans, and crustacean fragments could be detected, but were never abundant.

Bacterial contents of gastral cavities of Stoichactis giganteum, together with bacterial densities in the ambient water, are shown in Fig. 1. Although large variations occurred among the specimens tested, the number of bacteria in gastral cavities was always higher than that in the ambient water. Mean bacterial density in gastral cavities was $2.49 \times 10^{6}$ cells ml $\mathrm{ml}^{-1}$ $\left(\mathrm{SD}=1.07 \times 10^{6}\right)$, i.e. 2.6 times higher than in the ambient water. Rods constituted about $90 \%$ of bacterial numbers and $97 \%$ of bacterial biomass. Mean rodshaped bacterial density was $2.3 \times 10^{6}$ cells $\mathrm{ml}^{-1}$ $\left(\mathrm{SD}=1.1 \times 10^{6}\right), 14$ times higher than the density of rod-shaped bacteria in the ambient water. Cell dimensions of bacteria in the gastral cavities did not differ significantly from those in the ambient water.

Mucus-coated aggregations of particulate matter consisting mainly of spicules, animal and plant remains and sand grains - were most abundant in all anemones examined. These aggregates were of larger size (up to $5 \mathrm{~mm}$ ) than those found in ambient water samples. Indigestible items present in most of the gut contents consisted of solitary remains of exuvia originating from small crustacean plankters. Other planktonic organisms found in gut contents were foraminifera, diatoms, ostracods, zoeae and fish larvae. Remains of large benthic organisms were present in more than half of the gut contents tested. The remains of larger crabs consisted of leg-exuvia, $1.5 \mathrm{~cm}$ long, and antennae with lengths of 2.0 to $3.5 \mathrm{~cm}$. Furthermore, echinoid spines and whole mucus-coated brittle stars (5 cm diameter) of the genus Ophiothrix were recognized. During field work, Stoichactis giganteum were repeatedly observed egesting a whole echinoid test. Nearby, oral disks of $S$. giganteum, a large array of echinoderm spines and test remains, together with egested fine sand material, were found on the coarse sand bottom - reflecting the high contribution of echinoderms to heterotrophic anemone nutrition. Size and abundance of echinoderms and decapods in the study area imply that these animals provide important food sources for the anemone.

To obtain information on bacterial densities in the coelenteric fluid of Stoichactis giganteum, 1 anemone was starved and then fed. After $5 \mathrm{~d}$ of starvation the bacterial density had dropped from initially $4.6 \times 10^{5}$ $\left(\mathrm{SD}=1.23 \times 10^{5} ; \mathrm{n}=5\right)$ to $0.98 \times 10^{5}$ cells $\mathrm{ml}^{-1}$ $\left(\mathrm{SD}=0.88 \times 10^{5} ; \mathrm{n}=5\right)$ with a $32.7 \%$ contribution of rods. A net increase in bacterial density was observed after feeding within 4 to $5 \mathrm{~h}$. This increase was followed by a fast decrease, resulting in a density of rodshaped bacteria comparable to that at the beginning of the experiment. In a second experiment, 1 anemone 
was pre-starved for $4 \mathrm{~d}$, and coelenteric fluid was sampled over $12 \mathrm{~h}$, confirming the rhythmic variation of bacterial densities (Fig. 2a, b) observed in the previous experiment. After a sharp density increase, $2 \mathrm{~h}$ after feeding, and subsequent decrease lasting until 6 to $8 \mathrm{~h}$ after feeding, the bacterial density peaked again, repeating the cyclic variation.

The role of the coelenteric fluid in controlling bacterial density in starved and freshly-fed anemones, is indicated in Table 1. The bacterial density in the coelenteric fluid of starved anemones was always less than $2.3 \times 10^{5}$ cells ml-1 and in 4 out of 5 incubations a build up of bacterial density was observed ranging from $0.7 \times 10^{5}$ to $35.3 \times 10^{5}$ cells $\mathrm{ml}^{-1}$. In fed anemones, however, most incubation experiments demonstrated a digestion activity of the coelenteric fluid, indicated by a $t_{1} / t_{0}$ ratio less than 1 for all but 2 incubations, where bacterial densities at the begin of the incubation were low, $0.66 \times 10^{5}$ and $0.71 \times 10^{5}$ cells $\mathrm{ml}^{-1}$, respectively. When the calculated digestion

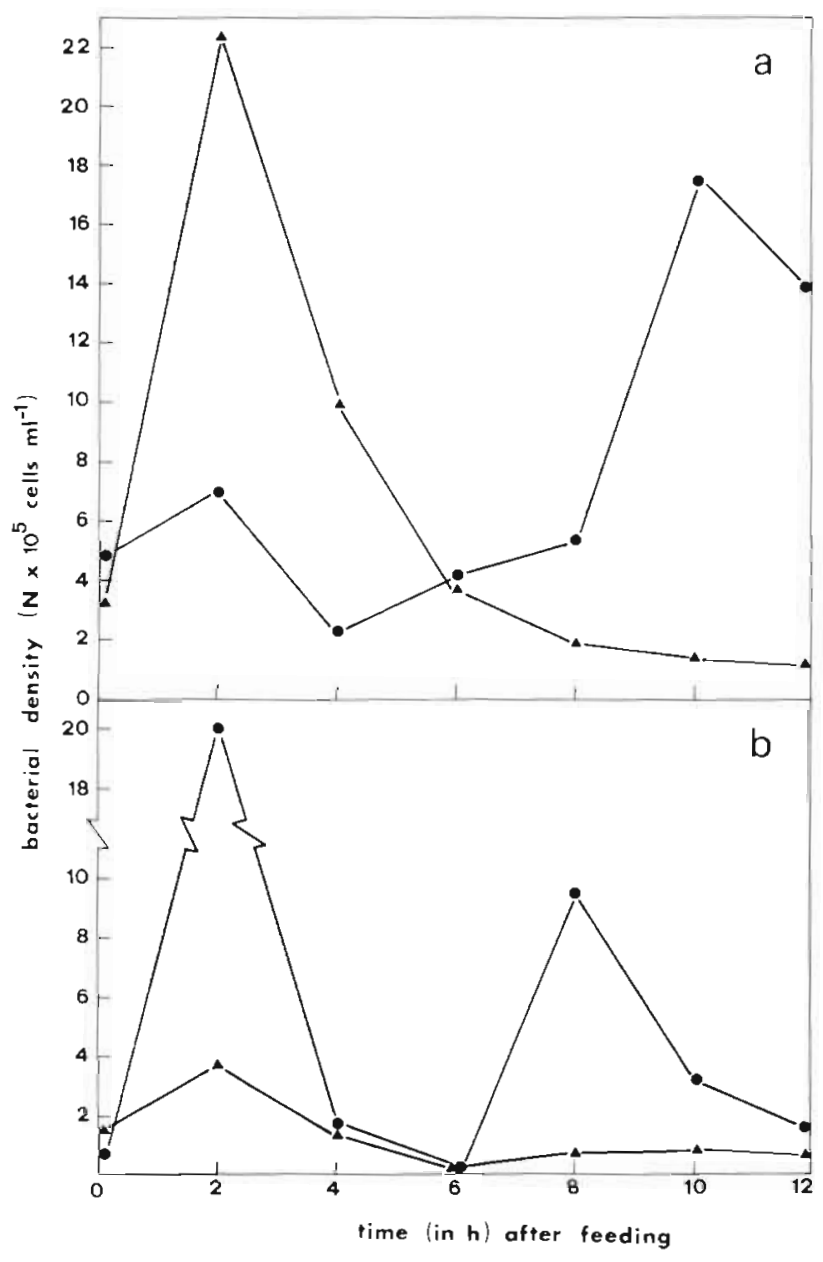

Fig. 2. Stoichactis giganteum. Development of bacterial densities in coelenteric fluid after feeding, followed over $12 \mathrm{~h}$ period; triangles: rods; circles: cocci

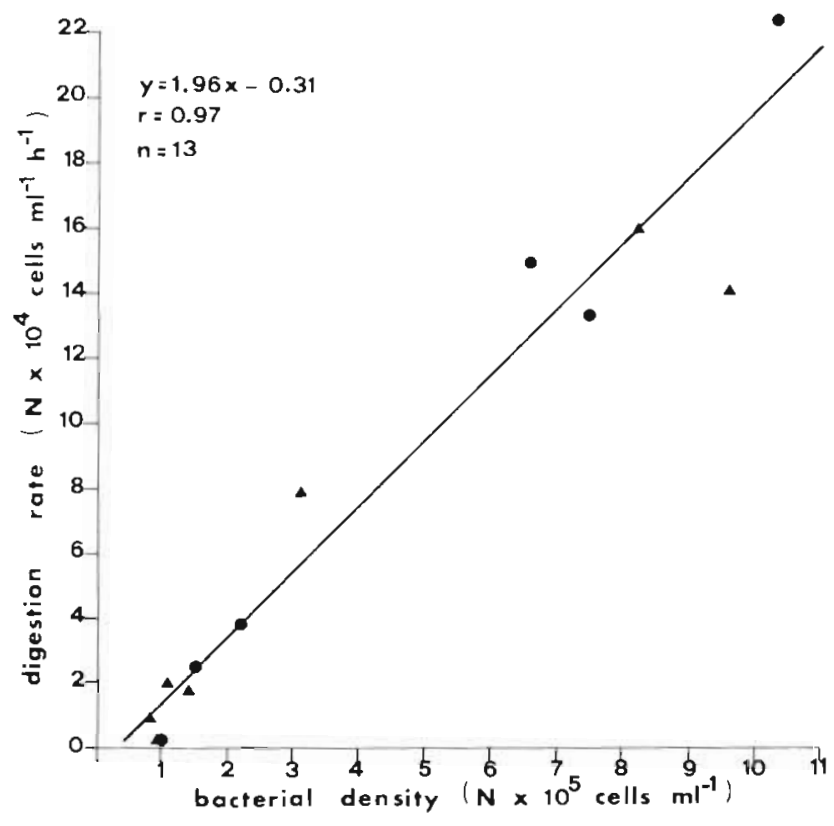

Fig. 3. Stoichactis giganteum. Interdependence between bacterial densities in gastral cavities and digestion ability of the coelenteric fluid; symbols as in Fig. 2

rate is plotted against bacterial density at the beginning of the incubation period, the regression demonstrates interdependence between digestion rate and initial bacterial density (Fig. 3). Digestion rates increase with increasing bacterial densities.

In $65 \% \quad(n=14)$ of the coelenteron contents examined, echinoderm and/or decapod remains were present. Both field and laboratory tests on the digestive ability of Stoichactis giganteum indicated that whole crustaceans (Ocypode cordimanus, Chlorodopsis areolata) and echinoderms (Tripneustes sp.) are ingested and that the indigestible items (i.e. exuvia) are rejected within $24 \mathrm{~h}$. It seems that all the remains of these benthic organisms had been ingested within $1 \mathrm{~d}$. In terms of biomass ingested, these benthic organisms probably provide the major component of heterotrophic nutrition for the anemone. Assuming a mean diameter of $7 \mathrm{~cm}$ for the most abundant Tripneustes species in the population off Ras Iwatine (Ebert 1982), 1 ingested sea urchin would contribute about $300 \mathrm{mg} \mathrm{N}$ to the heterotrophic energy gain of S. giganteum (calculated after Lilly 1975). Both the large diameter of the oral disk and its position close to the bottom, increase the probability for gathering large organisms ripped off the substratum by high current velocities. Furthermore, the oral disk with its large number of short tentacles may act as a sediment trap retarding the water layers close to the tentacles and therefore leading to a deposition of suspended solids which then stick to the mucus. Small crustacean zooplankters, such as copepods, provide another food source, as 
Table 1. Stoichactis giganteum. Bacterial density $\left(\mathrm{N} \times 10^{5}\right.$ cells $\left.\mathrm{ml}^{-1}\right)$ and biomass produced or digested ( $\mu$ g wet weight polyp $\left.{ }^{-1}\right)$ in the coelenteric fluid (CF) before and after incubation of CF for $4 \mathrm{~h}$ at $23^{\circ} \mathrm{C}$ under starved and various feeding conditions: (n af: time in $\mathrm{h}$ after feeding; nc: not counted)

\begin{tabular}{|c|c|c|c|c|c|c|c|c|c|}
\hline \multirow[t]{2}{*}{ Condition } & \multicolumn{3}{|c|}{ Rods } & \multicolumn{3}{|c|}{ Cocci } & \multicolumn{3}{|c|}{ Total } \\
\hline & Begin $\left(t_{0}\right)$ & End $\left(t_{1}\right)$ & Ratio $t_{1} / t_{0}$ & $\operatorname{Begin}\left(t_{0}\right)$ & End $\left(t_{1}\right)$ & Ratio $t_{1} / t_{0}$ & Begin $\left(t_{0}\right)$ & End $\left(t_{i}\right)$ & Ratio $t_{1} / t_{0}$ \\
\hline Starved & 0.089 & 0.267 & 3.0 & 0.059 & 0.44 & 7.45 & 0.148 & 0.707 & 4.7 \\
\hline Starved & 0.059 & 1.77 & 30 & 0.117 & 2.08 & 17.8 & 0.176 & 3.853 & 21.9 \\
\hline Starved & 0.307 & 4.807 & 15.6 & 0.213 & 2.537 & 11.9 & 0.52 & 7.344 & 14.1 \\
\hline Starved & 0.355 & 1.73 & 4.9 & 1.91 & 33.6 & 17.6 & 2.265 & 35.33 & 15.6 \\
\hline Starved & 0.8 & 0.4 & 0.5 & 1.01 & 0.34 & 0.33 & 1.81 & 0.74 & 0.4 \\
\hline \multicolumn{3}{|c|}{$\begin{array}{l}\text { Mean increase of } \\
\text { bact. density } \mathrm{ml}^{-1} \mathrm{CF} \mathrm{h}^{-1}\end{array}$} & 0.37 & & 1.78 & & & 2.15 & \\
\hline \multicolumn{2}{|c|}{$\begin{array}{l}\text { Mean bact. biomass } \\
\text { produced polyp } \mathrm{p}^{-1} \mathrm{~h}^{-1}\end{array}$} & & 4.94 & & 5.1 & & & 10.04 & \\
\hline $1 \mathrm{af}$ & 9.61 & 3.96 & 0.4 & nc & nc & - & - & - & - \\
\hline 1 af & 2.16 & 0 & 0 & nc & nc & - & - & - & - \\
\hline 2 af & 0.94 & 0.82 & 0.87 & 0.71 & 1.12 & 1.57 & 1.65 & 1.94 & 1.2 \\
\hline 3 af & 1.07 & 0.26 & 0.24 & 7.47 & 2.09 & 0.28 & 8.54 & 2.35 & 0.3 \\
\hline 4 af & 1.41 & 0.71 & 0.5 & 2.17 & 0.62 & 0.28 & 3.58 & 1.33 & 0.37 \\
\hline 4 af & 3.15 & 0 & 0 & 1.47 & 0.44 & 0.3 & 4.62 & 0.44 & 0.09 \\
\hline 5 af & 0.66 & 2.27 & 3.44 & 6.58 & 0.57 & 0.08 & 7.24 & 2.84 & 0.39 \\
\hline 6 af & 8.19 & 1.78 & 0.2 & 10.3 & 1.36 & 0.13 & 18.49 & 3.14 & 0.17 \\
\hline \multicolumn{3}{|c|}{ Mean digestion rate $\mathrm{mI}^{-1} \mathrm{CF} \mathrm{h}^{-1}$} & 0.68 & \multicolumn{3}{|c|}{1.14} & \multicolumn{3}{|c|}{1.82} \\
\hline \multicolumn{3}{|c|}{$\begin{array}{l}\text { Mean bact. biomass digested } \\
\text { polyp }{ }^{-1} h^{-1}\end{array}$} & 9.13 & \multicolumn{3}{|c|}{3.27} & \multicolumn{3}{|c|}{12.4} \\
\hline
\end{tabular}

indicated by a large amount of filter-cirri remains in the coelenteron. This is in agreement with Möller (1978), who found similar prey items in the Mediterranean sea anemone Anemonia sulcata.

The seeming contradiction between incubation experiments showing a digestion of bacteria in the isolated coelenteric fluid of fed specimens and the build up of bacterial density in the coelenteric fluid within the gastral cavity at the same time demonstrates that several parameters regulate bacterial densities. On the one hand, starved anemones seem to maintain the bacterial density above a certain level; on the other hand, high bacterial densities are being reduced by digesting the cells within 1 to $2 \mathrm{~h}$.

Compared with the potential nutritive value of the food items found in the gastral cavity, bacteria represent only a minor energy source. In terms of carbon, assuming a gastral-fluid volume of $200 \mathrm{ml}$ per anemone, the bacterial biomass digested represents $1.24 \times 10^{-3} \mathrm{mg} \mathrm{C}$ anemone $\mathrm{e}^{-1} \mathrm{~h}^{-1}$ in laboratory specimens; in terms of nitrogen, $3.54 \times 10^{-4} \mathrm{mg} \mathrm{N} \mathrm{h} \mathrm{N}^{-1}$ (see also Table 1). In the field (Fig. 1), bacteria in the coelenteron of Stoichactis giganteum represent about $1.0 \times 10^{-2} \mathrm{mg} \mathrm{C}$ and $2.84 \times 10^{-3} \mathrm{mg} \mathrm{N}$. Fitting the mean bacterial density of $2.49 \times 10^{6}$ cells $\mathrm{ml}^{-1}$ obtained from in situ investigations into the regression given in Fig.
3 , a calculated digestion rate of $4.8 \times 10^{5}$ cells ml-1 is obtained, indicating that the anemone digests $9.7 \times 10^{7}$ cells $\mathrm{h}^{-1}$ within the whole of its coelenteron, equivalent to $6.44 \times 10^{-3} \mathrm{mg} \mathrm{C} \mathrm{h}^{-1}$ or $1.84 \times 10^{-3} \mathrm{mg} \mathrm{N}$ $\mathrm{h}^{-1}$. Although it is assumed that high in situ digestion rates occur, bacterial carbon represents less than $1 \%$ of the calculated $1.14 \mathrm{mg} \mathrm{C} \mathrm{h}^{-1}$ of the respiratory carbon requirements.

In starved anemones, leaching of DOM from anemone and symbionts may be sufficient to guarantee energy for sustaining bacterial growth. The digestive activity of the coelenteric fluid against bacteria during phago- and pinocytosis of food items might well constitute an effective defense mechanism against microbial invasion and a strategy for reducing energy losses by exploiting the bacterial biomass itself. The high density of rod-shaped bacteria in the gastral cavity of Stoichactis giganteum obtained in situ indicates high nutrient availability in the coelenteron, since rods are generally characteristic of waters with a high amount of nutrients (Wiebe \& Pomeroy 1972, Ferguson \& Rublee 1976, Fuhrman \& Azam 1982).

We have demonstrated that Stoichactis giganteum utilizes a wide size range of prey - ranging from echinoderms to detrital matter - and have provided evidence that bacterial densities are controlled within 
the gastral cavity. Further work is required to analyse the mechanisms for controlling microbial population densities in the gastral cavity and to investigate the role of bacteria within the coelenteron of S. giganteum.

Acknowledgements. This study was supported by a grant from 'Hochschuljubiläumsstiftung' to $G$. J. Herndl and B. Velimirov, and by the 'Osterr Auslandsstudentendienst' of the University of Vienna to R. E. Krauss. We thank S. O. Allela, Director of the Kenya Marine and Fisheries Research Institute Mombasa (KMFRI) for providing research facilities, and especially A. Hillier for invaluable help. G. Krauss assisted during field work. We also thank Professor E. F. Abel and Dozent J. A. Ott for reading former drafts of the manuscript and for supporting us with laboratory facilities at the University of Vienna and Professor R. C. Newell for helpful comments on the manuscript.

\section{LITERATURE CITED}

DiSalvo, L. H. (1971). Regenerative functions and microbial ecology of coral reefs: labelled bacteria in a coral reef microcosm. J. exp. mar. Biol. Ecol. 7: 123-136

Ebert, T. A. (1982). Longevity, life history and relative body wall size in sea urchins. Ecol. Monogr. 52: 353-394

Ferguson, R. L., Rublee, P. (1976). Contribution of bacteria to standing crop of coastal plankton. Limnol. Oceanogr. 21: 141-145

Fuhrman, J. A., Azam, F. (1982). Thymidine incorporation as a measure of heterotrophic bacterioplankton production in marine surface waters: evaluation and field results. Mar. Biol. 66: 109-120

Hobbie, J. E., Daley, R. J., Jasper, S. (1977). A method for counting bacteria in Nuclepore filters. Appl. environ. Microbiol. 33: 1225-1228

Lasker, H. R. (1976). Intraspecific variability of zooplankton feeding in the hermatypic coral Montastrea cavernosa. In: Mackie, G. O. (ed.) Coelenterate ecology and behavior. Plenum Press, New York p. 101-109

Lewis, J. B. (1977). Suspension feeding in Atlantic reef corals and the importance of suspended particulate matter as a food source. In: Taylor, D. L. (ed.) Proc. Third Int. Coral Reef Symposium, Vol 1. University of Miami, Miami, p. 405-408

Lewis, J. B., Price, W. S. (1975). Feeding mechanisms and feeding strategies of Atlantic reef corals. J. Zool. Lond 176: $527-544$

Lilly, G. R. (1975). The influence of the diet on the growth and bioenergetics of the tropical sea urchin Tripneustes ventricosus. Ph. D. thesis, University of British Columbia

Möller, H. (1978). Nahrungsökologische Untersuchungen an Anemonia sulcata. Zool. Anz. 200: 369-373

Muscatine, L. (1973). Nutrition of corals. In: Jones, O. A., Endean, R. (eds,) Biology and geology of coral reefs, 2. Biology, Vol. 1. Academic Press, New York, p. 77-115

Muscatine, L. (1980). Productivity of zooxanthellae. In: Falkowski, P. G. (ed.) Primary productivity in the sea. Plenum Press, New York, p. 381-402

Porter, J. W. (1974). Zooplankton feeding by the Caribbean reef building coral Montastrea cavernosa. In: Great Barrier Reef Committee (ed.) Proc. Second Int. Coral Reef Symposium, Vol. 1. Great Barrier Reef Committee, Brisbane, p. 111-125

Porter, J. W. (1978). Coral feeding on zooplankton. In: Stoddart, D. R., Johannes, R. E. (eds.) Coral reef: research methods. Monogr. Oceanogr. Methodol. UNESCO, Paris, p. $515-522$

Reimer, A. A. (1971). Uptake and utilization of ${ }^{14} \mathrm{C}$-glycine by Zoanthus and its coelenteric bacteria. In: Lenhoff, H. M., Muscatine, L., Davis, L. V. (eds.) Experimental coelenterate biology. University of Hawaii Press, Honolulu, p. 209-217

Rodina, A. G. (1972). Methods in aquatic microbiology. University Press, Baltimore

Schlichter, D. (1978). On the ability of Anemonia sulcata (Coelenterata: Anthozoa) to absorb charged and neutral amino acids simultaneously. Mar. Biol. 45: 97-104

Sebens, K. P. (1977). Autotrophic and heterotrophic nutrition of coral reef zoanthids. In: Taylor, D. L. (ed.) Proc. Third Int. Coral Reef Symposium, Vol. 1. University of Miami, Miami, p. 397-404

Sorokin, Y. I. (1973). On the feeding of some scleractinian corals with bacteria and dissolved organic matter. Limnol. Oceanogr. 18: 380-385

Stephens, G. C. (1962). Uptake of glucose from solution by the solitary coral Fungia. Science, N. Y. 131: 1532-1534

Wiebe, W. J., Pomeroy, L. P. (1972). Micro-organisms and their association with aggregates and detritus in the sea: a microscopic study. In: Melchiorri-Santolini, U., Hopton, J. W. (eds.) Detritus and its role in aquatic ecosystems. Proc IBP-UNESCO Symp., Pallanza. Mem. Ist. ital. Idrobiol. 29 (Suppl.): 325-352

Accepted for printing on November 16, 1984 